\title{
The Military and its Civilian Environment: Reflections on a Theory of Civil-Military Relations
}

\author{
Gerhard Kümmel ${ }^{1}$
}

The study of what has come to be termed civil-military relations has received renewed interest within the last decade and, in my view, it is safe to assume that it is going to attract even more attention in the years to come. This situation may justify talking of nothing less than the renaissance of the study of civil-military relations. The reason for this renaissance seems to be that, in recent years, civil-military relations across the globe have entered a turbulent era, one that challenges - albeit with considerable variation - the established patterns of civil-military relations of the past. In particular, "[t]his renaissance in what some academics once considered a settled issue may be attributed to the emergence of post-cold war democracies in Eastern and Central Europe; to a (mostly) American quest to spread democratic norms throughout the world; to continued problems of imposing civil control over the military in many states, especially those where internal conflict seems endemic; and to a recent, but brief, interlude of American self-doubt about the effectiveness of civil control in the United States." Don Snider and Miranda Carlton-Carew add to these elements some others, such as the changes in the international system caused by the end of East-West conflict, the rapid downsizing of the armed forces that followed, and the increasing use of the military for operations other than war. ${ }^{3}$ These factors will be dealt with in this article, but prior to this, the talk of the renaissance of the study of civil-military relations leaves the reader with some obvious questions to be answered: What is actually meant by the term "civil-military relations"? To what does the term "established patterns" refer? In which direction are civil-military relations moving? Last but not least, underlying all these other issues is the question of whether there is an explanatory model or even a theory of civil-military relations that is capable of capturing all this. What follows is an attempt to respond to these questions.

\footnotetext{
${ }^{1}$ Gerhard Kümmel is Senior Researcher at the Bundeswehr Institute of Social Research (SOWI), Strausberg, Germany; President of the German Working Group on Armed Forces and Social Research (AMS); Executive Secretary of Research Committee 01: Armed Forces \& Conflict Resolution within the International Sociological Association (ISA).

2 Douglas L. Bland, "A Unified Theory of Civil-Military Relations," Armed Forces \& Society 26:1 (1999): 7.

${ }^{3}$ Don M. Snider and Miranda A. Carlton-Carew, "The Current State of U.S. Civil-Military Relations: An Introduction," in U.S. Civil-Military Relations in Crisis or Transition?, ed. Snider and Carlton-Carew (Washington, D.C.: Center for Strategic and International Studies, 1995), 8-14, as cited in Sam C. Sarkesian and Robert E. Connor, Jr., The U.S. Military Profession into the Twenty-First Century. War, Peace and Politics (London: Frank Cass, 1999), 81.
} 


\section{Civil-Military Relations: Approaching a Definition}

As can be inferred from the use of the expression "renaissance" above, the study of civil-military relations is by no means confined to the recent past. Indeed, civilmilitary relations and related issues have aroused the interest of a wide range of researchers coming from various academic disciplines, naturally following quite different approaches. For example, one theme of classical sociology is the debate over what has been termed the "incompatibility" of advanced industrial societies and their use of military force. This debate can be traced back to Auguste Comte, Herbert Spencer, and others and has, quite recently (in the 1980s) been radicalized by Wolfgang Vogt, who developed the ideal-type constructs of civilian logic and military logic, each being radically different from one another and thus increasingly coming to exclude one another. ${ }^{4}$ Max Weber, then, in his Economy and Society, undertook to analyze the military as a Stand, or a profession, and as a bureaucratic organization. Alfred Vagts, who published his classic History of Militarism before the Second World War, provided an intriguing historical account of militarism. ${ }^{5}$ Much later, Stanislav Andreski, in his often-neglected Military Organization and Society, studied the effects of armed forces on social structure and social stratification and their relevance for maintaining the position of social elites. ${ }^{6}$

By far the most important impact on the direction of the debate on civilmilitary relations, however, came from the political scientist Samuel P. Huntington, who wrote his seminal The Soldier and the State in $1957 .{ }^{7}$ By focusing on the officer corps, he revealed the potential conflict between the civilian desire for

\footnotetext{
${ }^{4}$ For the larger debate, see Günther Wachtler, ed., Militär, Krieg, Gesellschaft. Texte zur Militärsoziologie (Frankfurt: Campus, 1983). For Vogt's radical perspective, see Wolfgang R. Vogt, ed., Sicherheitspolitik und Streitkräfte in der Legitimationskrise. Analysen zum Prozess der Delegitimierung des Militärischen im Kernwaffenzeitalter (Baden-Baden: Nomos, 1983); Vogt, ed., Militär als Gegenkultur. Streitkräfte im Wandel der Gesellschaft I. (Opladen: Leske \& Budrich, 1986); and Vogt, ed., Militär als Lebenswelt. Streitkräfte im Wandel II (Leverkusen: Leske \& Budrich, 1988). Echoing Wilfried von Bredow, I do not follow Vogt's radical perspective, but rather propose that in the empirical social and political reality these different logics do not exist in pure, but in mixed forms; see von Bredow, Die Zukunft der Bundeswehr. Gesellschaft und Streitkräfte im Wandel. (Opladen: Leske \& Budrich, 1995), 22.

${ }^{5}$ Alfred Vagts, A History of Militarism. The Romance and Realities of a Profession. (New York: W.W. Norton, 1937)).

${ }^{6}$ Stanislav Andreski, Military Organisation and Society, ${ }^{\text {nd }}$ ed. (London: Routledge \& Kegan Paul, 1968).

${ }^{7}$ Samuel P. Huntington, The Soldier and the State. The Theory and Politics of Civil-Military Relations (Cambridge, MA: The Belknap Press of Harvard University Press, 1957). Peter Feaver argues that Huntington's book "has had the greatest and most lasting influence. It enjoys such longevity in part because it is a richly textured and insightful examination and in part because the American military, who endorse many $(. .$.$) of its general conclusions, have made it the$ centerpiece of their training on civil-military relations." Feaver, "The Civil-Military Problematique: Huntington, Janowitz, and the Question of Civilian Control," Armed Forces \& Society 23:2 (1996): 158.
} 
controlling the armed forces and the needs of military security. In his view, this tension could be managed by what he called "objective civilian control", the key to which was military professionalism and its attendant notions of military autonomy, political neutrality, and voluntary subordination. Yet, since at the time of his writing he interpreted the societal parameters as problematic, to say the least, because of what he perceived as the prevalence of American liberalism, his outlook for the American military was not optimistic, and his prognosis for American national security was grim: "The tension between the demands of military security and the values of American liberalism can, in the long run, be relieved only by the weakening of the security threat or the weakening of liberalism.." Leaving aside his criticism of American society, it is worth noting that Huntington's study served to shift the focus of research on civil-military relations to issues concerning the relationship between the military and the state, i.e. the government, thereby highlighting the predominant relevance of military professionalism as an instrument of civilian, governmental control of the military.

However, as others have noted - for example, Samuel Finer, Morris Janowitz, and Bengt Abrahamsson ${ }^{9}$ - the equation of military professionalism and voluntary subordination inherent in Huntingtonian thinking does not necessarily hold, because too many armed forces that were deemed professional, not only by their own standards but also by external evaluation, have engaged in various endeavors of subverting civilian authority, including coups d'etat. That is one major reason why the second chief protagonist in the debate on civil-military relations, Morris Janowitz, "understood civilian control in terms of societal control rather than state or institutional control. State institutions play a secondary role as an extension of society, but societal control, measured in part as integration with society, was Janowitz's normative and empirical focus." 10 Nevertheless, Janowitz also referred often to the idea of professionalism, but was ready to accept some degree of unavoidable politicization of the military because, in his perspective, given the international context of the nuclear age, the military increasingly had to operate on the concept of a constabulary force. ${ }^{11}$ Even more important to note is that his notion of "professional ethics," as he calls it, is dynamic and thus subject to change over time and is broader than Huntington's conception of professionalism. According to Janowitz, the officer is subject to civilian control not only because of "self-imposed professional standards," but also because of a "meaningful integration with civilian values." 12

\footnotetext{
${ }^{8}$ Huntington, Soldier and the State, 456.

${ }^{9}$ Samuel E. Finer, The Man on Horseback: The Role of the Military in Politics (London: Pall Mall Press, 1962); Morris Janowitz, The Professional Soldier. A Social and Political Portrait (New York: The Free Press, 1971 [1960]); Bengt Abrahamsson, Military Professionalization and Political Power (Beverly Hills, CA: Sage, 1972).

${ }^{10}$ Feaver, "Civil-Military Problematique," 166.

${ }^{11}$ See Janowitz, Professional Soldier, ch. 20.

12 Janowitz, The Professional Soldier, 420. This points to substantial differences between Janowitz
} 


\section{THE QUARTERLY JOURNAL}

Later on, echoing this proposition, Charles Moskos was to work on the wellknown I/O-model of military professionalism and its underlying distinction between institution and occupation. He argued that a shift could be observed from a model of military professionalism based on the notion of the military as an institution that is "legitimated in terms of values and norms, i.e., a purpose transcending individual self-interest in favor of a presumed higher good" to one based on the vision of the military as an occupation that is "legitimated in terms of the marketplace, i.e., prevailing monetary rewards for equivalent competencies."13

This short survey of contributions that have had and still have a major impact on the debate on civil-military relations reveals a number of topics that can be subsumed under that heading. However, this is only the tip of the iceberg; there are many more issues and topics in this field. This is the case because the term civilmilitary relations is broadly understood as the encompassing relations between the armed forces and the soldiers on the one hand and the non-military, civilian world on the other. In order to structure these various topics, civil-military relations can be broken into several dimensions in which civilians may encounter the military and vice versa.

Before presenting these various dimensions, it is necessary to clarify that this approach implies that the armed forces are sufficiently different from the rest of society for them to be conceived of as a distinguishable entity. Indeed, many scholars point to a "need for [the] armed forces to remain apart from society with a distinctive organizational structure and culture or ethos in order to do its job."14 Bernard Boëne, in an intriguing article, has referred to this as the issue of military uniqueness, i.e. the essential "question of how unique the military really is - and ought to be." 15 The answer he gives is not straightforward: "If anything, it [his article] has shown the subject of military distinctiveness to be a most complex issue. The answer varies according to whether the comparison runs in terms of social structure, recruitment, skill requirements, culture, lifestyles, degree of social and political integration into the parent society, legal status, or any other trait.". Nevertheless, his answer is basically affirmative, because a few lines later he concludes, "There are, however, a few permanent, universal traits, related to the sacred character of war for any society, once it has embarked on such a course

and Huntington in their treatment of military autonomy. Furthermore, it is to be emphasized that both Huntington and Janowitz apply the concepts of military professionalism and professional ethics to officers only; see Gwyn Harries-Jenkins, "The Concept of Military Professionalism," Defense Analysis 6:2 (1990), 122.

${ }^{13}$ Charles C. Moskos, "From Institution to Occupation. Trends in Military Organization," Armed Forces \& Society 4:1 (1977): 42, 43.

${ }^{14}$ Christopher Dandeker, "The Military in Democratic Societies: New Times and New Patterns of Civil-Military Relations," in Military and Society in $21^{\text {st }}$ Century Europe. A Comparative Analysis, ed. by Jürgen Kuhlmann and Jean Callaghan (Hamburg: Lit, 2000), 29.

${ }^{15}$ Bernard Boëne, "How 'Unique' Should the Military Be? A Review of Representative Literature and Outline of a Synthetic Formulation,” European Journal of Sociology 31 (1990): 3. 
- obedience, loyalty, unlimited liability for service, a stronger degree of coercive institutional authority - as well as to its violent nature (transgression of civilian taboos)." ${ }^{16}$ Other authors agree. Martin Edmonds, for example, notes "that armed services [as Edmonds prefers to say] fulfill a highly specialized function, the effect of which is to separate them entirely, and geographically to a great extent, from civil society." ${ }^{17}$ Christopher Dandeker writes: "The military is unique in the nature and extent of the demands it places upon its personnel. They are obliged to train to kill and to sacrifice self, to participate in a military community where one works, lives and socializes with other service personnel and, when, necessary, to respond to a 24-hour commitment with the risk of separation from family at short-notice." 18

In the eyes of many observers, an adequate theoretical framework to capture this uniqueness of the armed forces is offered by systems theory and is provided in Martin Edmonds's Armed Services and Society. In this vein, the armed services can be thought of as a system that is distinct from its environment and that operates, in its interacting and interdependent component parts, on its own system of logic. Thus the system (or rather the sub-system) of the armed forces can be analyzed in terms of its relationship to its environment and to other (sub-) systems that are working and operating within this environment.

Having said this, for analytical reasons I propose to distinguish six interdependent and interpenetrated dimensions in an attempt to cover the full scope of civil-military relations: economy, finance, technology, culture, society, and politics. ${ }^{19}$ Next, it is advisable to keep in mind that these various dimensions of civil-military relations may, most likely, look quite different depending on the moment in time that they are observed. In other words, the time factor has to be included in the analysis. Here I suggest differentiating between civil-military relations in: (1) peacetime, (2) crisis situations, (3) traditional military operations (defense, deterrence, attack), and (4) non-traditional military operations (peacekeeping, humanitarian intervention, etc.). Furthermore, since the civilian side has both a national and an international face, these six dimensions have to be seen in a national/domestic perspective as well as in an international context. According to the scheme resulting from this tableau, research issues can be grouped to-

\footnotetext{
${ }^{16}$ Boëne, "How 'Unique' Should the Military Be?" 58.

${ }^{17}$ Martin Edmonds, Armed Services and Society, IUS Special Editions on Armed Forces and Society no. 2 (Boulder: Westview Press, 1990), 43. At the same time, he points to key linkages between the military and society that do remain.

${ }^{18}$ Christopher Dandeker, Flexible Forces for the Twenty-First Century, Facing Uncertainty Report no. 1 (Karlstad: Department of Leadership, Swedish National Defense College, 1999), 85.

${ }^{19}$ This is inspired by Edmonds, Armed Services and Society, 113; and Bernard Boëne, Wilfried von Bredow, and Christopher Dandeker, "The Military in Common-Risk Societies. Elements of Comparison Among Nine Countries of West, Central, and East Europe," in Kuhlmann and Callaghan, eds., esp. 319-325. Both works differentiate between the economic, political, societal, and cultural dimensions.
} 


\section{THE QUARTERLY JOURNAL}

gether. The following table gives some examples of research topics that fall into the various categories and illustrate that the study of civil-military relations is an interdisciplinary undertaking (see table page 69).

Taking this broader view, the study of civil-military relations is thus richer than is often assumed, since the common view has it that the study of civilmilitary relations is confined to purely social arenas, and especially to politics. To a substantial degree, this impression is corroborated by the fact that the bulk of research on civil-military relations is dedicated to these two dimensions. It needs to be underlined that there is more to the research of civil-military relations than just society and politics, although the majority of research is done in these two areas and, of course, there are good reasons for this.

\section{The Civil-Military Problematique}

The reasons for this special focus of research on civil-military relations towards societal and political questions are basically rooted in what Peter Feaver has termed the "civil-military problematique." This problem is by no means a recent one, nor even one of the modern era, and has already received the intellectual and political attention of a good number of political thinkers and philosophers. Among them, for example, is Plato who dwelt upon it in the Third Book of his Republic. This problem rests upon two central and potentially conflicting principles: "First, the military must be strong enough to prevail in the society's wars," and second, "just as the military must protect the polity from enemies, so must it conduct its own affairs so as not to destroy the society it is intended to protect." Therefore, the military is deemed to be subordinate to the political authority of the state; "while it should be large enough to protect against threats, its size and draw on society's resources must be bounded." 20 As a consequence, the problem is one of striking the appropriate balance between the military's functional and socio-political imperatives. $^{21}$

This civil-military problematique originates in the processes of functional differentiation and specialization within society that have occurred over time. The trend towards a division of labor in the development of societies implies that a society, or rather the government that a given society has chosen or has to live with, delegates the task of providing security for the respective society to some of its members. This segment came to be called the military. However, the military as a sub-group of the larger society, and as an instrument of a given government, commands substantial power resources, power resources that generally surpass those of the government. This begs the question of why the armed services should follow what they are being told to do by civilians. Herein lies what Feaver calls the civil-military challenge, which is about reconciling "a military strong enough to

\footnotetext{
${ }^{20}$ Feaver, "The Civil-Military Problematique," 151, 152, 153.

${ }^{21}$ See Boëne, "How 'Unique' Should the Military Be?"
} 
Table: The Dimensions of Civil-Military Relations and Examples for Research Topics

\begin{tabular}{|c|c|c|}
\hline Dimension & National Context & International Context \\
\hline Economy & $\begin{array}{l}\text { The military's economic } \\
\text { relevance as a consumer } \\
\text { of goods with special } \\
\text { economic importance for } \\
\text { certain regions contri- } \\
\text { buting to economic } \\
\text { stability. } \\
\text { The armed forces and the } \\
\text { armaments industry. }\end{array}$ & $\begin{array}{l}\text { The military's economic } \\
\text { relevance as a consumer } \\
\text { of goods in peacekeeping } \\
\text { missions contributing to } \\
\text { economic reconstruction. }\end{array}$ \\
\hline Finance & $\begin{array}{l}\text { Military expenditures and the } \\
\text { overall state budget. }\end{array}$ & $\begin{array}{l}\text { The armed services as a } \\
\text { recipient of international } \\
\text { military aid and of } \\
\text { international credits. }\end{array}$ \\
\hline Technology & $\begin{array}{l}\text { The military as a promoter of } \\
\text { technological progress } \\
\text { within a country. }\end{array}$ & $\begin{array}{l}\text { Export of military technology } \\
\text { and armaments. }\end{array}$ \\
\hline Culture & $\begin{array}{l}\text { The military's importance } \\
\text { within the political culture } \\
\text { of a country (the "weight } \\
\text { of history"). } \\
\text { Portrayal of armed services } \\
\text { in a nation's cultural } \\
\text { products (literature, music, } \\
\text { film, theater, etc.). }\end{array}$ & $\begin{array}{l}\text { Impact of the presence of } \\
\text { foreign armed forces on a } \\
\text { country's political culture. } \\
\text { Portrayal of foreign armed } \\
\text { forces in a nation's cultural } \\
\text { products (literature, film, } \\
\text { music, theater, etc.). }\end{array}$ \\
\hline Society & $\begin{array}{l}\text { Perception of armed services } \\
\text { within a country's society. } \\
\text { The military's distinctiveness } \\
\text { from and integration into a } \\
\text { country's society. }\end{array}$ & $\begin{array}{l}\text { The armed forces and } \\
\text { encounters with society in } \\
\text { the location of a given } \\
\text { mission abroad. } \\
\text { Perception of peacekeeping } \\
\text { forces within the society of } \\
\text { the country in which the } \\
\text { peacekeeping mission is } \\
\text { conducted. }\end{array}$ \\
\hline Politics & $\begin{array}{l}\text { Political control of the armed } \\
\text { services. } \\
\text { The role of the military in } \\
\text { politics. }\end{array}$ & $\begin{array}{l}\text { Political control of } \\
\text { multinational military } \\
\text { missions. } \\
\text { Political-military interface in } \\
\text { alliances. }\end{array}$ \\
\hline
\end{tabular}




\section{THE QUARTERLY JOURNAL}

do anything the civilians ask them to with a military subordinate enough to do only what civilians authorize them to do. This is a special problem of political agency: how do you ensure that your agent is doing your will, especially when your agent has guns and so may enjoy more coercive power than you do?"22 Bernard Boëne put the dilemma this way: "how can a society effectively (safely and, on its own terms, harmoniously) manage its relation to those responsible for its security?"23 This, then, is the primary issue of civilian control of the military as it fits into the larger landscape of civil-military relations research. ${ }^{24}$

Civilian control of the armed services is a fundamental and essential question to those societies that have armed forces, regardless of whether the government is a democratic, monarchic, theocratic, authoritarian, or totalitarian one. ${ }^{25}$ The reason for this is that the military is inherently ambivalent in its character. We can see from the long history of the military that there have been numerous cases in which the armed services did not follow the orders given to them by civilians in government. Also, at times, militaries have acted in non- or even anti-democratic ways - for example, serving as an instrument to overthrow democratic political systems. This can be seen when looking at some Latin American, African, Asian, and even Western countries and, in particular, at the number of attempted or successful coups d'etat in these regions. However, this is only one side of the coin. The other is that there have been cases in which the military served as a conditio sine qua non in endeavors to defend a democracy against its attackers. In this vein it should also be mentioned that, in certain cases, the armed forces have served as a supporter of the transition to democracy. ${ }^{26}$

Since the armed services obviously are a double-edged sword, so to speak, it is no wonder that the relationship between the armed forces and society and the issue of civilian control of the military are of substantial social-scientific and also

\footnotetext{
${ }^{22}$ Feaver, "Civil-Military Problematique," 149.

${ }^{23}$ Boëne, "How 'Unique," 27.

${ }^{24}$ It is important to note that the term "civilian control" is a general one in the sense that it does not make distinctions between societies according to their degree of democratization. Hence, for democratic/democratizing societies, the more normative notion of democratic control has been proposed; see Wilfried von Bredow and Gerhard Kümmel, "New Roles for the Armed Forces and the Concept of Democratic Control," in Civil-Military Relations in an Age of Turbulence: Armed Forces and the Problem of Democratic Control, ed. by Gerhard Kümmel and Wilfried von Bredow, SOWI-Forum International no. 21 (Strasbourg: SOWI, 2000), 126.

${ }^{25}$ Following the recent independence of East Timor, at present (July 2002) there are 193 states in the world. More than 10 percent of them (22) have no established armed services. The countries free of armed forces are: Andorra, Costa Rica, Dominica, Grenada, Haiti, Kiribati, Liechtenstein, Maldives, Mauritius, Monaco, Nauru, Panama, Saint Lucia, Saint Vincent \& the Grenadines, San Marino, Solomon Islands, Samoa, St. Kitts \& Nevis, Tuvalu, Vanuatu and, last but not least, Vatican City.

${ }^{26}$ A prominent example would be the Western powers, especially the United States, that brought democracy to Germany after World War II, an endeavor in which the armed forces were of crucial importance.
} 
societal and political concern. This is particularly true for democratic societies, the number of which has risen since the end of the Cold War, as can easily be inferred from Freedom House's annual publication Freedom in the World. In recent years, the question of civilian control has been vigorously debated, especially with regard to Eastern European countries and the successor states of the Soviet Union. ${ }^{27}$ In democracies, there is a basic feeling that the existence of the armed forces requires institutions, mechanisms, and instruments for the political and democraticsocietal control of the military in order to prevent the isolation of the military from society and to prevent the armed forces from turning into an imperium in imperio, thereby constituting a potential threat to the political rule of a given legitimate government. This involves both a "hardware" and a "software" side, as Douglas Bland convincingly argues. ${ }^{28}$ In his approach, the "hardware" of civil-military relations (or rather civilian control of the military) covers such aspects as the creation of appropriate laws, the establishment of civilian-dominated ministries of defense, the institutionalization of parliamentary committees of oversight, and the appointment of civilian ministers of defense. The "software" of civilian control of the armed services refers to the incorporation of the framework of democratic ideas, values, principles, and norms into the military culture, the political culture, and the defense establishments of new democracies. According to his view, the "hardware" dimension is usually quite adequately realized in emerging democracies, whereas the "software" side is more difficult to put into practice, since it deals with the thinking of the people involved and requires that this change. ${ }^{29}$ This incorporation can be successfully implemented only if the change in thinking and the orientation towards a new democratic future are not only proclaimed rhetorically, but also proceed in reality - a process which is likely to take some time.

This mention of the need to instill democratic norms into military culture indicates the importance of broadening our view. So far, the question of civilian control of the armed services has largely been viewed from a civilian perspective. However, since there is a military side to the issue of civilian control, it is also necessary to look at how to change the viewpoint of the military. Here it is quite obvious that the armed forces have a robust interest in not being exposed to undue interference from the civilian side, an interest that in particular entails the exis-

\footnotetext{
${ }^{27}$ See, inter alia, James Gow, Legitimacy and the Military: The Yugoslav Crisis (London: Pinter Publishers, 1992); Anton A. Bebler, ed., Civil-Military Relations in Post-Communist States (London: Praeger, 1997); Constantine Danopoulos and Daniel Zirker, eds., Military and Society in the Former Soviet Bloc (Boulder: Westview Press, 1998); Kuhlmann and Callaghan, eds., Military and Society in $21^{\text {st }}$ Century Europe; and Andrew Cottey, Timothy Edmunds, and Anthony Forster, eds., Democratic Control of the Military in Postcommunist Europe: Guarding the Guards (New York: Palgrave, 2002).

${ }^{28}$ Douglas L. Bland, "Patterns in Liberal Democratic Civil-Military Relations," Armed Forces \& Society 27:4 (2001): 525.

${ }^{29}$ For a discussion of the Westminster/American tradition see Bland, "Patterns," esp. 529-536.
} 


\section{THE QUARTERLY JOURNAL}

tence or the establishment of provisions aimed at preventing the political misuse of the military for partisan political objectives or for reasons of a given government's political survival. In Michael Howard's words, this is the problem "of the control of a government in possession of such force" [the armed forces]. ${ }^{30}$ In such a vein, the Soviet government's political control of the armed forces represented what could be termed the excessive version of political control, and is proof of the fact that the military, as an institution of the state, might not in all cases be capable of rejecting, or at least restricting, undue political interference. ${ }^{31}$ Yet what can be said of legitimate civilian control is that it obviously requires the agreement and the consent of the armed services to be operable and effective. Accordingly, the military's "voluntary and purposeful adherence to the principle of civilian control" is essential, and even a prerequisite, to ensuring civilian control. ${ }^{32}$. This very fact has aroused some uneasiness, given that "the civil authority has legitimacy, but the armed forces have the guns" as Douglas Bland writes. He adds, "Even if the idea of civil control is embedded in the officer corps, one cannot avoid the conclusion that it resides there because officers accept it, not because the civil authority has imposed it," leaving the somewhat awkward impression that, in the end, the civilian side comes close to being at the mercy of the armed forces. ${ }^{33}$

\section{Civilian Control as a Regime of Shared Responsibility}

So far in this article, I have, in the first step, developed an overall model of civil-military relations that distinguishes six dimensions of civil-military relations, takes account of both national and international contexts, and reflects what they are doing at the time that they are being observed. In the second step, I have focused on those aspects and dimensions of civil-military relations that have received the bulk of scholarly attention: the civil-military problematique, i.e., the issue of the civilian control of the armed services. ${ }^{34}$ In the third step, I will present more recent approaches to developing a coherent and comprehensive theory of civil-military relations, or rather of civilian control of the armed forces. Thus this article distinguishes between an overall model of civil-military relations and a more specific theory of civilian control.

\footnotetext{
${ }^{30}$ Michael Howard, Soldiers and Governments: Nine Studies in Civil-Military Relations (London: Eyre \& Spottiswoode, 1957), 12.

${ }^{31}$ See, for example, Timothy J. Colton and Thane Gustafson, Soldiers and the Soviet State. CivilMilitary Relations from Brezhnev to Gorbachev (Princeton, NJ: Princeton University Press, 1989).

${ }^{32}$ Peter D. Feaver, Guarding the Guardians: Civilian Control of Nuclear Weapons in the United States (Ithaca, NY: Cornell University Press, 1992), 253.

${ }^{33}$ Bland, "Patterns," 529.

${ }^{34}$ David Segal notes that, "[t]he central issue in theories of civil-military relations is that of civilian control of the military." Segal, "Civil-Military Relations in Democratic Societies," in Armed Forces at the Dawn of the Third Millennium, SOWI Forum International no. 16, ed. Jürgen Kuhlmann and David R. Segal (Munich: SOWI, 1994), 40.
} 
Peter Feaver has identified four benchmarks such a theory should meet. First, it should start from the analytical distinction between the civilian and military spheres; second, the theory should identify the factors that shape the exercise of control over the military by civilians; third, the theory needs to transcend the concept of professionalization; and, fourth, he recommends that such a theory should be developed deductively. ${ }^{35}$ Douglas Bland adds to these four benchmarks some further criteria: first, the theory should cover all the relevant "issues" within one model; second, it should not only be applicable to democracies, but should be transferable to any state or political model; third, it must be able to explain change over time; fourth, it has to provide substantial predictability across borders, time, and events; and, fifth, it should be falsifiable. ${ }^{36}$ Bland has made strong efforts to meet these criteria. His regime theory approach, adapted from the discipline of international relations, and his sketch of a theory of shared responsibility arguably represent the most innovative recent endeavors in this field.

His theory of shared responsibility makes two key assumptions: first, civilian control "means that the sole legitimate source for the direction and actions of the military is derived from civilians outside the military/defense establishment," ${ }^{37}$ and, second, that it "is a dynamic process susceptible to changing ideas, values, circumstances, issues, and personalities and to the stresses of crises and war." 38 Shared responsibility is based on the notion "that civil control of the military is managed and maintained through the sharing of responsibility for control between civilian leaders and military officers. Specifically, civil authorities are responsible and accountable for some aspects of control and military leaders are responsible and accountable for others." 39 They form what he terms a "regime," for which he employs Stephen Krasner's classic definition as being the "principles, norms, rules and decision making procedures around which actor expectations converge, ${ }^{40}$ This implies that "leaders in both entities must understand how these principles, norms, and rules affect the routine functioning of their relationship, and their place in the process - in sum, how the regime might guide and direct their individual and collective behavior in civil-military relations." 41

\footnotetext{
${ }^{35}$ Feaver, "Civil-Military Problematique," 167-170.

${ }^{36}$ Bland, "Unified Theory," 9.

${ }^{37}$ This assumption is somewhat problematic. Imagine a situation in a democracy in which the ruling civilian government's objective is to change from a democratic political system to an autocratic or authoritarian one. If we follow Bland's assumption, the armed services should remain neutral, but would it not be desirable in normative terms if, along with other actors, the armed forces tried to prevent this from happening?

${ }^{38}$ Bland, "Unified Theory," 10.

${ }^{39}$ Ibid., 9.

${ }^{40}$ Krasner, as cited in Bland, "Unified Theory," 10. In a similar vein, James Gow, in Legitimacy and the Military, used the notion of a "social contract" between soldiers and the socio-political community (27-32).

${ }^{41}$ Bland, "Patterns," 536.
} 


\section{THE QUARTERLY JOURNAL}

Accordingly, Bland speaks of national regimes of civilian control that have developed and changed over the course of time due to a country's specific history, geopolitical/strategic situation, and political culture. This implies that civilian control is "conceptualized not just as a shield against the coup d'etat, but as an exercise in the management of a regime that legitimizes and restricts the actions of all the players in the interest of society." 42 As a result, such an approach to accounting for the study of regime change and regime dynamics allows for the fruitful analysis of civilian control over time, across various political systems, and across various social and cultural contexts. "Thinking of civil-military relations as anarchy controlled by a regime that links basic causal variables to behavior provides a way of relating actions to actors that transcends specific states, times, and situations. The examination of how such regimes are formed and maintained can bring history into the debate. ... It also helps to identify the foundations for civilmilitary relations where current rules (laws) and decision-making procedures are based on other fundamental national principles and norms." ${ }^{43}$

The specific configuration within any such regime of civil-military relations at a given point in time accounts for and explains the outcomes in "four central decision matrices in defense management: strategic decisions about the ends and means of defense; organizational decisions about the arrangement of defense resources and internal responsibilities; social decisions about armed forces and society; and operational decisions about the employment of forces." 44 Since decisionmaking is a genuinely political undertaking, this means accepting the notion of the military as a political actor or, as Morris Janowitz has put it, as "an effective pressure group," thereby questioning the widespread notion of the military's political neutrality in its hypertrophied version. In particular with regard to decisions on the use of force, the armed services expect to be consulted and listened to; if not, the alienation of the armed forces from their civilian authorities may ensue. ${ }^{45}$ This points to Peter Feaver's notion of "delegative control," which he juxtaposes with what he calls "assertive control," and it also takes up Rebecca Schiff's plea for building consensus. ${ }^{46}$

In the end, then, a civil-military relations regime, or, rather, civilian control of the military regime, will be effective if there is a basic resource at hand for all the parties involved and if that resource is available in sufficient quantity. This resource is trust, and trust is strengthened as additional internal control mechanisms

${ }^{42}$ Bland, "Unified Theory," 20.

${ }^{43}$ Ibid., 16.

${ }^{44}$ Ibid., 11.

45 Janowitz, The Professional Soldier, lvi; see also Richard Betts, Soldiers, Statesmen, and Cold War Crises (New York: Columbia University Press, 1991).

${ }^{46}$ Feaver, Guarding the Guardians, 7-9; Rebecca Schiff, "Civil-Military Relations Reconsidered: A Theory of Concordance," Armed Forces \& Society 22:1 (1995): 7-24. 
are implemented on all the parties involved. ${ }^{47}$ Yet talking of trust implies that uncertainty cannot be completely washed away. ${ }^{48}$ Thus it may be appropriate to expand Douglas Bland's formula of civilian control of the armed services because it, in the most part, entails that the armed forces and the civil authorities are only two of the ingredients. In this case Bland's concept requires that society itself be brought back into the equation. Indeed, Bland tends to neglect society in his formula by not treating society, or parts of it, as an actor in regimes of civil-military relations in its own right; he merely treats society as some sort of a background variable without any weight of its own. Thus, his regime theory of civilian control stresses the political/governmental/administrative side of civilian control and tends to overlook the societal side of civilian control, which is particularly relevant in the case of democracies. Following democratic theory, in democracies in particular society legitimizes its government and authorities, and thus also its armed forces. Therefore, "the legitimacy of the military in relation to society is dependent on societal acceptance of the military's role(s), and the military's ability to fulfill the demands of that roles(s) effectively." 49 This legitimacy of the armed services within society is to be seen as a major and essential asset in order for any military mission to be effective and successful. ${ }^{50}$

The logical way forward, then, seems to be to include societal control within Bland's regime approach. Resonating with Rebecca Schiff's concordance theory, resolving the issue of civilian control of the military is thus a major task for any given government as well as for society at large and for the military itself. These tripartite regimes of civilian control of the armed services face the challenging task of striking a balance between the interests of all parties involved.

\section{Outlook: Challenges of the $21^{\text {st }}$ Century}

In this last section, I will attempt to give a rough overview of the challenges facing civil-military relations in general and civilian control of the armed forces in particular. These challenges refer to changes in both the domestic and international environments of the armed services that result in mounting pressure upon the military to adapt to these changes, which in turn puts civil-military relations and the issue of civilian control of the armed services on the agenda.

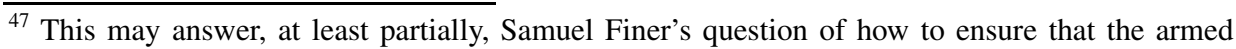
forces will refrain from major political interference; see Finer, The Man on Horseback, 5.

${ }^{48}$ See Niklas Luhmann, Vertrauen. Ein Mechanismus der Reduktion sozialer Komplexität. 3. durchgesehene Auflage (Stuttgart: Ferdinand Enke, 1989).

${ }^{49}$ Edmunds, et al., The Military and Society in Central and Eastern Europe, 8.

${ }^{50}$ That is why Bernard Boëne writes, "Socio-political uniqueness [of the military] is superimposed on functional uniqueness. The two dimensions are analytically distinct but not independent." Boëne, "How 'Unique,” 57.
} 


\section{THE QUARTERLY JOURNAL}

\section{The international environment}

The international climate for the majority of the $20^{\text {th }}$ century was shaped by the Cold War as the dominant structuring conflict of international politics. At its root was ideological disagreement - the antagonistic differences between the respective models of society that translated into power-political and security-political dimensions ${ }^{51}$. The build-up of nuclear forces made this conflict particularly worrisome to many, as the world faced a potential nuclear holocaust. Deterrence became the major function of the armed services. 1989 marked the end of the Cold War, and indeed amounted to a break with international relations as it had been practiced since the Second World War. The implosion of the Soviet Union and the ensuing collapse of the Soviet empire fundamentally changed the world's political configuration. The rather clear-cut and straightforward structure of international politics as a result of the Cold War gave way to a much more messy world order, with different regions and zones varying in their degree of security. ${ }^{52}$

In a sense, then, it might be argued that, for most people, the world has not become a safer place. In contrast to the hopes of a benign, pleasant, harmonious, peaceful, and prosperous world, possibly governed by a much more powerful United Nations (UN), and in contrast to the democratic and market-economic triumphalism proclaimed in Francis Fukuyama's well-known proposition of the end of history, the world instead witnessed the persistence of military conflicts, unilateralism, and the ongoing use of military force as well as the continued expenditure of substantial financial resources on weapons production and procurement. ${ }^{53} \mathrm{Al}-$ though there was a reduction of the armed forces in many countries, and although armament expenditures showed signs of decrease in others, in the end the hopes for a peace dividend were dashed.

In today's world order, there is no single structural conflict that shapes almost all the other conflicts in the international system as the Cold War had done until 1989. Instead, there are many conflicts, some of which sometimes overlap and reinforce each other. To a substantial degree, these conflicts do not resemble the conflicts of the past, where states were fighting each other. By contrast, conflicts in the emerging world order increasingly stem from internal rifts within states, between different groups within society, and from the collapse of state structures. ${ }^{54}$ Faced with so-called humanitarian catastrophes that ensued from such conflicts in

\footnotetext{
${ }^{51}$ Ernst-Otto Czempiel, Weltpolitik im Umbruch. Das internationale System nach dem Ende des Ost-West-Konflikts (Munich: Beck, 1991).

${ }^{52}$ See Joseph S. Nye, "What New World Order?" Foreign Affairs 71:2 (1992): 83-96.

${ }^{53}$ Francis Fukuyama, Das Ende der Geschichte. Wo stehen wir? (Munich: Kindler, 1992).

${ }^{54}$ See Joel S. Migdal, Strong Societies and Weak States. State-Society Relations and State Capabilities in the Third World (Princeton, NJ: Princeton University Press, 1988); William I. Zartman, ed., Collapsed States. The Disintegration and Restoration of Legitimate Authority (Boulder: Lynne Rienner, 1995); and Robert I. Rotberg, "The New Nature of Nation-State Failure," The Washington Quarterly 25:3 (2002): 85-96.
} 
the 1990s, and the subsequent demonstration of cosmopolitan concern for human rights in the world, the role of the military was expanded to include peacekeeping, peace enforcement, humanitarian intervention, and military missions other than war. Thus it makes sense to distinguish between traditional and non-traditional roles of the armed services. ${ }^{55}$ September 11, the horrible synonym for the terrorist challenge to world order, also deserves mention in this regard as it implies a further diversification of military roles in the response to the significant change of the face of war and warfare. ${ }^{56}$

Underlying all this are the processes of globalization that have gained momentum since the end of the Cold War. ${ }^{57}$ Globalization, in fact, is the prime mover in international relations. It is an asymmetrical process with costs and benefits being unevenly distributed between states and societies, but also within them. As a result, there is opposition to globalization as, for example, expressed in the fragmentation of various (political, economic, cultural, religious, ethno-national) brands. Globalization is also a multi-dimensional phenomenon that can be observed in the economy, the financial system, the ecosphere, communication, demographics, and in security and military affairs. Across these fields, the basic characteristic is de-bordering or trans-bordering, i.e. the transgression of territorial boundaries. Globalization means an increase in links across borders and interactions between states and between members of their societies leading to what Robert Keohane and Joseph Nye Jr. (1977) termed "complex interdependence." ${ }^{\text {A }}$ Although globalization and the density of interdependence varies across the world because of different interdependence costs and benefits and because of different degrees of interdependence susceptibility and vulnerability, the global arena has increasingly become the focus and framework of social action for all societies. This implies that the security of a given country can be influenced and threatened by events in far away places. This means, in turn, that the security policies of each country have to take the global aspects of security into consideration. Security, in most cases, cannot be established by focusing only on the near abroad.

\section{The national environment}

Armed forces are armed forces of a specific political system and of a specific society at a specific point in time. For the West - broadly speaking, the members

\footnotetext{
${ }^{55}$ See von Bredow and Kümmel, "New Roles for the Armed Forces."

${ }^{56}$ See Martin van Creveld, The Transformation of War (New York: Free Press, 1991); Martin Shaw, Post-Military Society. Militarism, Demilitarization and War at the End of the Twentieth Century (Philadelphia: Temple University Press, 1991); Kalevi J. Holsti, The State, War, and the State of War (Cambridge: Cambridge University Press, 1996); and George and Meredith Friedman, The Future of War. Power, Technology and American World Dominance in the Twenty-First Century (New York: St. Martin's Press, 1998).

${ }^{57}$ See, for example, Malcom Waters, Globalization, $2^{\text {nd }}$ ed. (London: Routledge, 1996).

${ }^{58}$ Robert O. Keohane and Joseph S. Nye, Power and Interdependence. World Politics in Transition (Boston: Little, Brown \& Co., 1977).
} 


\section{THE QUARTERLY JOURNAL}

of the OECD plus some newly industrializing countries - development in this regard within nation-states and their societies can be subsumed under the headings of social change and value change. These changes strongly influence the life of the people, the life of the soldiers, and the conditions for the operation of social institutions. These changes come under different headings; Ronald Inglehart, in his seminal study on the Silent Revolution, argues that in modern societies a shift is perceptible from materialistic to post-materialistic attitudes and value orientations. In opposition to the traditional emphasis on material security and wellbeing, attitudes and values have emerged that place emphasis on participation, aesthetics and self-fulfillment. Living a good life in a healthy (ecologically safe) environment is deemed desirable by a significant and growing portion of society. ${ }^{59}$

This resonates with more recent analyses such as Ulrich Beck's. According to Beck, the process of individualization is still in its very beginnings and will gain much more importance and social impact in the decades to come. The individual is forced to put him/herself center stage in conceptualizing life and dealing with living conditions fundamentally characterized by risk. In this society as outlined by Beck, the risks caused by the vagaries and vicissitudes of life have to be shouldered by individuals who have lost the social safety net provided by either the family or by the other members of society. ${ }^{60}$ A correlated phenomenon to this move to post-materialism is the emergence of what Gerhard Schulze calls the "sensational society" (Erlebnisgesellschaft), in which there is a trend among the younger generation towards hedonism and fun-seeking. ${ }^{61}$ Others perceive a shift to a post-modern society that is accompanied by a rise of relativist orientations. ${ }^{62}$

Other trends are at work in the domestic environment as well. Due to decreasing birth rates and simultaneously increasing life expectancies, there is a demographic revolution under way in advanced societies. The aging of society is accompanied by the erosion of traditional forms of family life and partnership and the prevalence of one-child families. The women's movement has not only resulted in a growing percentage of women in higher education, but also, although not to the same extent, in mounting numbers of women at work both in economics and in politics. Women can increasingly be found among the working population, thus challenging traditional gender roles.

\footnotetext{
${ }^{59}$ Ronald Inglehart, The Silent Revolution. Changing Values and Political Styles Among Western Publics (Princeton, NJ: Princeton University Press, 1977).

${ }^{60}$ Ulrich Beck, Risikogesellschaft. Auf dem Weg in eine andere Moderne (Frankfurt: Suhrkamp, 1986).

${ }^{61}$ Gerhard Schulze, Die Erlebnisgesellschaft. Kultursoziologie der Gegenwart, $2^{\text {nd }}$ ed. (Frankfurt: Campus, 1992).

${ }^{62}$ Bernard Boëne, "Post-Cold War Trends in the Civil Control of Armed Forces in the West," in Civil-Military Relations in an Age of Turbulence, eds. Kümmel and Bredow, 11-31.
} 


\section{The adaptive military}

Since in democratic societies there is public pressure towards transparency and public participation in all issue areas, and since democracy and liberalization/democratization have become major elements in the international normative order that even non-democratic states have to refer to, there is a pressure towards the democratization of security politics and of the armed forces themselves. ${ }^{63}$ For example, this can be seen in the debate about the unionization of soldiers. The armed services are increasingly under pressure to instill democratic norms such as decentralized decision-making, greater individual participation, increased flow of information, and transparency of structure. This poses new challenges to leadership in the military as it entails a shift towards "de-layering" and project management. ${ }^{64}$

In addition, for armed forces living in a "political society" undergoing a communication revolution, there is a need to be constantly aware that military operations and actions as well as developments within the armed forces can rapidly become a matter of large-scale public attention and of media scrutiny. ${ }^{65}$ In an era in which "we are witnessing an increased capacity of public opinion to exercise its political influence in ways that transcend the boundaries of states," public opinion and the media have both a national/domestic and an international face. ${ }^{66}$ Within such a context, problems related to the political management of the use of coercive force may increase.

Democratization also implies that the armed forces will encounter social movements dealing with issues of human rights, peace, ecology, gender, emancipation, and so on. Most importantly, these movements have put issues on the military agenda that are not easily digested by the armed forces, but are instead highly contested matters. This refers to questions of social equality as reflected in the debate on including women and homosexuals in the armed forces. ${ }^{67}$ Since global migration is more likely to increase than to diminish over time, multicultural societies are developing that face the questions of whether and, if so, how various ethnic and religious groups and other segments of society can be integrated into the armed services.

The impact of the value shift required in this regard may be substantial, because of a presumed growing discrepancy between military and civilian values and value systems. Whereas the armed services emphasize authority, obedience, duty,

\footnotetext{
${ }^{63}$ See Günther Baechler, "10 Thesen zur Demokratisierung der Sicherheitspolitik," Sicherheit und Frieden 7:1 (1989): 27-31.

${ }^{64}$ Dandeker, "Flexible Forces," 87.

${ }^{65}$ See Michael Th. Greven, Die politische Gesellschaft. Kontingenz und Dezision als Probleme des Regierens und der Demokratie (Opladen: Leske \& Budrich, 1999).

${ }^{66}$ Dandeker, "The Military in Democratic Societies," 31.

${ }^{67}$ See Joseph Soeters and Jan van der Meulen, eds., Managing Diversity in the Armed Forces. Experiences from Nine Countries (Tilburg: Tilburg University Press, 1999).
} 


\section{THE QUARTERLY JOURNAL}

community, comradeship, discipline, and patriotism, the latter stress individuality, self-fulfillment, autonomy, cosmopolitanism, and consumption. ${ }^{68}$ In the end, this may result in a trend towards the departure of large numbers of individuals from the armed forces. In countries with conscription, this may be inferred from and demonstrated by the mounting numbers of conscripts who choose civil service instead of military service. The overall trend seems to be that societies become "indifferent" towards their armed services. ${ }^{69}$ Although the overall prestige of the armed forces is considerable, not least due to their noble image as peacekeepers, the personal inclination of individuals to join the armed services seems to be declining.

In most parts of the world, the end of the Cold War led to a downsizing of the military, and expectations ran high concerning a peace dividend and, in some areas, also a marginalization of the military. Although this did not happen in the way that some had hoped, there have been cuts in defense expenditures, and there has also been a reduction of personnel. This has left an imprint upon soldiers serving in the armed forces in terms of thwarted motivation. These reductions also implied the closure of bases, which means that the armed services have become less visible in public life; their presence in everyday life is less pronounced than before. An additional result is that there are fewer people in society with firsthand, personal experience of the military. ${ }^{70}$

The military has been forced to adapt to other changes brought about by the end of the Cold War as well. As mentioned above, globalization confronts the actors in international relations with potential security threats that are global in scope and also with what can be termed the humanitarian impulse, or the "something must be done factor." ${ }^{\prime 11}$ As a result, there has been a broadening of the range of foreign missions undertaken and an increase in their number. To deal with these issues and the ensuing problems, the actors have intensified their efforts to establish multinational military co-operation. As a matter of fact, we are witnessing the multinationalization of the armed forces, be it within the framework of the United Nations and its peacekeeping operations or in the context of specific alliances and ad hoc coalitions, thus leading to the question of how to ensure the civilian control of multinational military operations. ${ }^{72}$

\footnotetext{
${ }^{68}$ See Elmar Wiesendahl, "Wertewandel und motivationale Kriegsunfähigkeit von Streitkräften," Sicherheit und Frieden 8:1 (1990): 25-29; and Ekkehard Lippert, "Die Bundeswehr im Wertespagat," in Bredow, Die Zukunft der Bundeswehr, 125-128.

${ }^{69}$ Charles C. Moskos, "Towards a Postmodern Military: The United States as a Paradigm," in The Postmodern Military. Armed Forces After the Cold War, eds. Charles Moskos, John Allen Williams, and David R. Segal (New York: Oxford University Press, 2000), 15.

${ }^{70}$ Dandeker, "Flexible Forces," 91.

${ }^{71}$ Christopher Dandeker, "New Times for the Military: Some Sociological Remarks on the Changing Role and Structure of the Armed Forces of the Advanced Societies," in The Sociology of the Military, ed. Giuseppe Caforio (Cheltenham: Edward Elgar, 1998), 579.

${ }^{72}$ See Gerhard Kümmel and Paul Klein, "The Internationalization of Military Life. Necessity,
} 
Within this military multinationalization/globalization, issues of organizational interoperability, cultural interoperability, mutual understanding, and of effective military co-operation are central. Christopher Dandeker writes of the "complex set of arrangements among a mixture of military and civilian agencies, including NGOs, the media and regional political organizations" that are necessary to enable military forces from all over the world to work together on the new breed of multinational mission. ${ }^{73}$

It may be argued that in multinational peacekeeping operations a new sense of the soldier's mission emerges. The soldier is no longer only a fighter, a technician, or a bureaucrat; instead he increasingly becomes a diplomat, a policeman, and a global street worker. Non-traditional military roles do not supplant the traditional roles of the armed forces, but they do expand them, thus increasing the number of military operations, which may in turn lead to mission fatigue for soldiers (and their families). ${ }^{74}$ The armed forces are thus far from losing political relevance. Rather, they gain new political importance by taking over new and non-traditional roles. Indeed, the "boundary between what is military and what is political has become blurred," implying that there are "more frequent opportunities for politicalmilitary conflict." 75

To meet these various mission requirements and functional imperatives the armed services, as a general rule, have become smaller, leaner, more modular, more flexible, and more technology-oriented, and are increasingly operating on the "matrix format" and on an all-volunteer format. ${ }^{76}$ Taken together, these developments underline the assumption of Charles Moskos and James Burk, who perceive a transition from the modern mass army and the late-modern large professional army to a post-modern smaller professional military. ${ }^{77}$ Moskos, Williams,

Problems and Prospects of Multinational Armed Forces," in Military Sociology. The Richness of a Discipline, eds. Gerhard Kümmel and Andreas D. Prüfert (Baden-Baden: Nomos, 2000): 311-328; and Bredow and Kümmel, "New Roles for the Armed Forces," 128.

${ }^{73}$ Dandeker, "Flexible Forces," 81.

${ }^{74}$ See Bredow and Kümmel, "New Roles for the Armed Forces."

${ }^{75}$ Dandeker, "The Military in Democratic Societies," 42ff; Boëne, "Post Cold-War Trends," 24.

${ }^{76}$ Boëne, Bredow, and Dandeker, "The Military in Common-Risk Societies," 319. Viewed from an international perspective, then, conscription seems to be phasing out. This will involve new challenges for recruitment policies. As regards the technologically-induced revolution in military affairs that aims "at the elimination of uncertainty in military action through technological means" (Boëne 2000: 21), one major keyword is information warfare (Boëne, "Post Cold-War Trends," 21). See, inter alia, Dorothy E. Denning, Information Warfare and Security (Boston: AddisonWesley, 1999). Correlated with this is the presumed casualty aversion of advanced democratic societies that has led to an increased reluctance in employing ground combat troops; see, e.g., James Burk, "Support for Peacekeeping in Lebanon and Somalia: Assessing the Casualties Hypothesis," Political Science Quarterly 114:1 (1999): 53-78; and Philip Everts and Pierangelo Isernia, eds., Public Opinion and the International Use of Force (London: Routledge, 2001). As the events following September 11 have indicated, this may change, at least partially.

${ }^{77}$ Charles C. Moskos and James Burk, "The Postmodern Military," in The Sociology of the Military, ed. Caforio, 592. 


\section{THE QUARTERLY JOURNAL}

and Segal also write of a post-modern military that "undergoes a loosening of the ties with the nation-state. The basic format shifts toward a volunteer force, more multipurpose in mission, increasingly androgynous in makeup and ethos, and with greater permeability with civilian society." ${ }^{, 78}$ Despite this greater permeability, however, there is some concern that "the tensions between the civilian values of democratic society and the unique structure and culture of the military" may increase in the future. ${ }^{79}$

Within a "post-modern" military based on the all-volunteer format, we "may see an increase in the proportion of those in the rank and file who are singlemindedly pro-military, and possibly alienated from society, entailing the emergence of far-right ideologies and politicization." ${ }^{80}$ Among others, this implies the "distinct possibility that radical professionalism and a more uncooperative military culture will return." 81 As a remedy, the strengthening of pragmatic professionalism has been advocated. ${ }^{82}$ In a Janowitzian tradition of human resource policy and management, "the expected result would be to foster role models that strengthen dual identities as soldiers and citizens, to the detriment of hardened corporate identities." 83 In a similar vein, there is the notion of a "post-deferential military ethos" that needs to be constructed that "meets the operational needs of the military, as well as meeting the demands of modern business and contemporary social values." 84

As can be inferred from this survey, the fields of civil-military relations and the civilian control of the armed services are influenced by many factors. Some of the established patterns of civilian control of the past will persist, others may have to be modified, and still others may have to be thoroughly revised. Change is with us, and further change is on the horizon; it remains to be seen how this change will be managed. These are interesting times, then, for practitioners and students of civil-military relations and of the civilian control of the military.

\footnotetext{
${ }^{78}$ Charles C. Moskos, John Allen Williams, and David R. Segal, "Armed Forces After the Cold War," in The Postmodern Military, eds. Moskos, Williams, and Segal, 1.

79 Dandeker, "Flexible Forces," 93.

${ }^{80}$ Boëne, "Post-Cold War Trends," 21.

81 Ibid., 22.

${ }^{82}$ For Arthur Larson, radical professionalism means that the soldiers view themselves as being on duty twenty-four hours a day, whereas pragmatic professionalism tries to balance the functionally unique and non-unique elements of the military and to constantly work for a balanced relationship with society. See Larson, "Military Professionalism and Civil Control: A Comparative Analysis of Two Interpretations," Journal of Political and Military Sociology 2:1 (1974): $57-72$.

${ }^{83}$ Boëne, "Post-Cold War Trends," 25.

${ }^{84}$ Dandeker, "The Military in Democratic Societies," 35; Dandeker, "Flexible Forces," 93.
} 


\section{Bibliography}

Andreski, Stanislav. Military Organisation and Society. London: Routledge \& Kegan Paul, 1968.

Baechler, Günther. "10 Thesen zur Demokratisierung der Sicherheitspolitik." Sicherheit und Frieden 7, no. 1 (1989).

Bebler, Anton A.. Civil-Military Relations in Post-Communist States . London: Praeger, 1997.

Beck, Ulrich. Risikogesellschaft. Auf dem Weg in eine andere Moderne . Frankfurt: Suhrkamp, 1986.

Beck, Ulrich. Risikogesellschaft. Auf dem Weg in eine andere Moderne . Frankfurt: Suhrkamp, 1986.

Bland, Douglas L.. "A Unified Theory of Civil-Military Relations." Armed Forces \& Society 26, no. 1 (1999).

Bland, Douglas. "Patterns in Liberal democratic Civil-Military Relations." Armed Forces and Society 24, no. 7 (2001): 525-540.

Boëne, Bernard. "How 'Unique' Should the Military Be? A Review of Representative Literature and Outline of a Synthetic Formulation." European Journal of Sociology 31 (1990).

Burk, James. "Support for Peacekeeping in Lebanon and Somalia: Assessing the Casualties Hypothesis." Political Science Quarterly 114, no. 1 (1999).

Czempiel, Ernst-Otto. Weltpolitik im Umbruch. Das internationale System nach dem Ende des Ost-West-Konflikts . Munich: Beck, 1991.

Dandeker, Christopher. "New Times for the Military: Some Sociological Remarks on the Changing Role and Structure of the Armed Forces of the Advanced Societies." In The Sociology of the Military. Cheltenham: Edward Elgar, 1998.

Dandeker, Christopher. "The Military in Democratic Societies: New Times and New Patterns of Civil-Military Relations." In Military and Society in 21st Century Europe. A Comparative Analysis., 2000.

Dandeker, Christopher. Flexible Forces for the Twenty-First Century, Facing Uncertainty Report no. 1 . Karlstad: Department of Leadership, Swedish National Defense College, 1990.

Danopoulos, Constantine, and Daniel Zirker. Military and Society in the Former Soviet Bloc . Boulder: Westview Press, 1998.

Feaver, Peter D.. Guarding the Guardians: Civilian Control of Nuclear Weapons in the United States. Ithaca, NY: Cornell University Press, 1992.

Finer, Samuel E.. The Man on Horseback: The Role of the Military in Politics . London: Pall Mall Press, 1962.

Friedman, George, and Meredith Friedman. The Future of War. Power, Technology and American World Dominance in the Twenty-First Century . New York: St. Martin's Press, 1998. 
Fukuyama, Francis. Das Ende der Geschichte. Wo stehen wir? . Munich: Kindler, 1992.

Gow, James. Legitimacy and the Military: The Yugoslav Crisis. London: Pitter Publishers, 1992.

Greven, Michael Th.. Die politische Gesellschaft. Kontingenz und Dezision als Probleme des Regierens und der Demokratie. Opladen: Leske \& Budrich, 1999.

Holsti, Kalevi J.. The State, War, and the State of War. Cambridge: Cambridge University Press, 1996.

Howard, Michael. Soldiers and Governments: Nine Studies in Civil-Military Relations. London: Eyre \& Spottiswoode, 1957.

Huntington, Samuel P.. The Soldier and the State: The Theory and Politics of CivilMilitary Relations. Cambridge, MA: Harvard University Press, 1985.

Inglehart, Ronald. The Silent Revolution. Changing Values and Political Styles Among Western Publics . Princeton, NJ: Princeton University Press, 1977.

Inglehart, Ronald. The Silent Revolution. Changing Values and Political Styles Among Western Publics . Princeton, NJ: Princeton University Press, 1977.

Keohane, Robert O., and Joseph S. Nye. Power and Interdependence. World Politics in Transition. Boston: Little, Brown \& Co, 1977.

Managing Diversity in the Armed Forces. Experiences from Nine Countries . Tilburg: Tilburg University Press, 1999.

Militär, Krieg, Gesellschaft. Texte zur Militärsoziologie . Frankfurt: Campus, 1983.

Moskos, Charles C.. "From Institution to Occupation. Trends in Military Organization." Armed Forces \& Society 4, no. 1 (1977).

Moskos, Charles C.. "Towards a Postmodern Military: The United States as a Paradigm." In The Postmodern Military. Armed Forces After the Cold War. New York: Oxford University Press, 2000.

Nye, Joseph S.. "What New World Order?" Foreign Affairs 72, no. 1 (1992): 83-96.

Rotberg, Robert I.. "The New Nature of Nation-State Failure." The Washington Quarterly 25, no. 3 (2002): 85-96.

Shaw, Martin. Post-Military Society. Militarism, Demilitarization and War at the End of the Twentieth Century . Philadelphia: Temple University Press, 1991.

Snider, Don M., and Miranda A. Carlton-Carew. "The Current State of U.S. CivilMilitary Relations: An Introduction." In U.S. Civil-Military Relations in Crisis or Transition?. Washington, D.C.: Center for Strategic and Internatonal Studies, 1995.

Vagts, Alfred. A History of Militarism. The Romance and Realities of a Profession. . New York: W.W. Norton, 1937.

von Bredow, Wilfried, and Gerhard Kümmel. "New Roles for the Armed Forces and the Concept of Democratic Control." In Civil-Military Relations in an Age of Turbulence: Armed Forces and the Problem of Democratic Control., 2000. 
Wiesendahl, Elmar. "Wertewandel und motivationale Kriegsunfähigkeit von Streitkräften." Sicherheit und Frieden 8, no. 1 (1990).

Zartman, William I.. Collapsed States. The Disintegration and Restoration of Legitimate Authority . Boulder: Lynne Rienner, 1995. 